\section{NEUROGLIA. MORPHOLOGY AND} FUNCTION

By P. Glees, M.A., D.Phil., M.D. Pp. xii + I I I with 45 illustrations. Oxford: Blackwell Scientific Publications. 1955. 25s.

As claimed by the author in his Foreword, the chief value of this monograph will be as a guide to more extensive reading for those such as neuropathologists, who have a special interest in the neuroglia and its problems. The field covered is very wide, including a historical introduction, an account of the morphological characteristics and histogenesis of the different types of neuroglial cells, their functions under normal and pathological conditions, the age changes in neuroglia and the significance of neuroglial cells in relation to the problem of brain metabolism.

The attempt to cover so wide a field and such an extensive literature in a short monograph has resulted (almost inevitably) in a catalogue of detailed observations, few of which can be discussed critically or correlated with each other in the space available. It is difficult, therefore, to obtain any clear overall picture from it, although it may well be that in this particular subject our knowledge has not yet advanced far enough for any clear picture to be possible. It would have been helpful, however, if the various observations reported were arranged a little more systematically and if some guide could have been given as to which were the more reliable or could be regarded as well established. One would have liked to find more of the author's own observations described and illustrated, and to be informed of his own conclusions in relation to the many difficult problems which are mentioned.

For these reasons this monograph will be of little value to any who have not already some special knowledge in the field dealt with; for research workers it will be a useful introduction to the literature, although its usefulness would have been greatly increased if more indication had been given of the relative merits and importance of the numerous investigations which are referred to. Perhaps the most important general conclusion one can draw after reading this book is that even the morphological classification of different types of neuroglial cells is far more difficult and controversial than the elementary textbook would lead one to suppose, and that one's ideas about the functions of the neuroglia are still in most cases little better than speculations.

\section{CARDIAC ANOMALIES}

By Vincent Moragues, M.D., and Chester P. LYNXWILER, M.D. Pp. $x+92$, with 157 illustrations. London: Ballière, Tindall \& Cox, Ltd. 1954. 5os.

This book is essentially a pictorial diagnostic manual covering most forms of congenital heart disease. The authors correlate the pathological anatomy and physiology of the abnormal circulation and include X-ray and E.C.G. findings. A briuf summary is given of medical and surgical treatments available at the present time.

There is no doubt that this publication will found very useful to medical students and practitioners in search of a rapid presentation of the subject, but it is not full enough to meet the needs of a worker in this specialized field.

A firm understanding of the anatomy of the abnormal heart can only come by handling an examining fresh specimens, it cannot be gained fro inspection of black and white two-dimensional photographs. In this book many of the photo graphs are of poor quality and convey very little. The diagrammatic representations of the state of affairs are better but a few gross errors of scale and anatomy are to be found, notably in the relation of the vagus nerve to the ductus arteriosus in the section on coarctation of the aorta.

However, this book does fill a gap and there is great deal in it of tremendous value.

\section{EMERGENCIES IN MEDICAL PRACTICE}

Edited by C. AllaN BIRCH, M.D., F.R.C. Fourth edition. Pp. xii + 6ro, with 143 illusira tions, 9 in colour. Edinburgh: E. \& S. Liveg్ $\overrightarrow{g-}$ stone Ltd. 1954. 30s.

In the preface to this latest edition of deservedly popular work, the Editor quites Michelet: 'Un livre est toujours un moyem faire un meilleur livre.' Dr. Birch and his 80 laborators, by revising the whole of the prevos edition, have achieved what might have thought to have been almost the impossible.

This excellently produced book covers a vast field, ranging from the hazards of medical pres cedures to the taking of a dying declaration, and contains an enormous amount of information, well presented and easy to assimilate rapidly in emergency.

It should form an essential part of the equipmest of every houseman, casualty officer and general practitioner.

\section{THE LIVER AND CANCER}

By Kasper Blond, M.D., F.I.C.S. Pp. xii + $22 . \bar{g}$. Bristol: John Wright \& Sons, Ltd. I $95 \overline{5}$ : 27s. 6d.

In his pilgrimage toward the Mecca of the curre of cancer, the author leans heavily upon the staff of logic and draws deep draughts of refreshment from the chalice of Peller's work, 'Cancer in Man.'

His major premise is that carcinoma is under the influence of environment and not heredity; extern $₫$ irritants clearly cause external carcinoma, whito ingested irritants in the form of drugs, diet an drink cause internal carcinoma. The book fI directed to the mechanisms by which the liver fai in its task of inactivating these internal irritants.

I.L.E. $\stackrel{\oplus}{\oplus}$ 